\title{
A COMPARATIVE STUDY OF HAEMODYNAMIC EFFECTS AND INTUBATION CONDITIONS OF ROCURONIUM BROMIDE VERSUS SUXAMETHONIUM
}

\author{
M. Srinivasa Rao ${ }^{1}$, T. V. V. S. V. Prasad ${ }^{2}$, Sailaja ${ }^{3}$,Kumudha D. $A^{4}$
}

${ }_{1}^{1}$ Associate Professor, Department of Anaesthesia, S. V. Medical College/S. V. R. R. Government General Hospital, Tirupathi, A. P. India. ${ }^{2}$ Assistant Professor, Department of Anaesthesia, S. V. Medical College/S. V. R. R. Government General Hospital, Tirupathi, A. P. India. ${ }_{3}^{3}$ Postgraduate Student, Department of Anaesthesia, S. V. Medical College/S. V. R. R. Government General Hospital, Tirupathi, A. P. India. ${ }^{4}$ Postgraduate Student, Department of Anaesthesia, S. V. Medical College/S. V. R. R. Government General Hospital, Tirupathi, A. P. India. ABSTRACT

\section{BACKGROUND}

Suxamethonium chloride was a time-tested depolarising muscle relaxant with quick onset of action and produced excellent intubating conditions, but it is contraindicated and hazardous in certain situations. Rocuronium bromide had the most rapid onset, intermediate duration of action, minimal cardiovascular side effects and with no histamine release, emerged as a good alternative.

The present study was undertaken to evaluate the efficacy of rocuronium bromide in comparison to succinylcholine for use during rapid sequence induction of anaesthesia. Fifty patients posted for elective surgeries were divided into two groups of 25 each randomly. Group S received succinylcholine $1.5 \mathrm{mg} / \mathrm{kg}$ and Group R received rocuronium bromide of $0.9 \mathrm{mg} / \mathrm{kg}$. Laryngoscopy and intubation was done at 60 seconds after assessing the relaxation of jaw, vocal cords status and response to intubation using a standard intubation scoring system by a double-blind assessor. Results were tabulated and analysed using appropriate statistical methods. Excellent intubating conditions were seen in 100\% of Group S and 90\% in Group R respectively. Haemodynamic changes returned to pre-induction baseline values by the end of 5 minutes in both groups. Hence, we concluded that rocuronium bromide was a safer and a good alternative to succinylcholine for rapid sequence intubation of anaesthesia in adult patients where succinylcholine was contraindicated provided that there was no anticipated difficulty in intubation.

\section{MATERIALS AND METHODS}

The present study was undertaken to evaluate the efficacy of rocuronium bromide in comparison to succinylcholine for use during rapid sequence induction of anaesthesia. Fifty patients posted for elective surgeries were divided into two groups of 25 each randomly. Group S received succinylcholine $1.5 \mathrm{mg} / \mathrm{kg}$ and Group R received rocuronium bromide $0.9 \mathrm{mg} / \mathrm{kg}$. Laryngoscopy and intubation was done at 60 seconds after assessing the relaxation of jaw, vocal cords status and response to intubation using a standard intubation scoring system by a double-blind assessor.

\section{RESULTS}

Results were tabulated and analysed using appropriate statistical methods. Statistical analysis was done using the software Statistical Package of Social Science version 20. Excellent intubating conditions were seen in 100\% of Group S and $90 \%$ of Group R respectively.1,2,3 Haemodynamic changes returned to pre-induction baseline values by the end of 5 minutes in both groups.

\section{CONCLUSION}

Hence, we concluded that rocuronium bromide was a safer and a good alternative to succinylcholine for rapid sequence intubation of anaesthesia in adult patients, where succinylcholine was contraindicated provided that there was no anticipated difficulty in intubation.

\section{KEY WORDS}

Intubating Conditions, Rocuronium Bromide, Succinylcholine.

HOW TO CITE THIS ARTICLE: Rao MS, Prasad TVVSV, Sailaja, et al. A comparative study of haemodynamic effects and intubation conditions of rocuronium bromide versus suxamethonium. J. Evolution Med. Dent. Sci. 2018;7(26):3058-3063, D0I: $10.14260 /$ jemds/2018/686

\section{BACKGROUND}

Maintenance of patient's airway is a basic and essential component of general anaesthesia. Endotracheal intubation is one of the available means of doing so in common day-to-day practice.

'Financial or Other Competing Interest': None.

Submission 14-03-2018, Peer Review 09-06-2018,

Acceptance 15-06-2018, Published 25-06-2018.

Corresponding Author:

M. Srinivasa Rao,

Associate Professor,

Department of Anaesthesiology,

S. V. Medical College,

Tirupathi, Andhra Pradesh, India.

E-mail: manduri60@gmail.com

DOI: $10.14260 /$ jemds $/ 2018 / 686$
Muscle relaxants and enable laryngoscopy and intubation. Rapid sequence induction and orotracheal intubation is an established technique to secure a patent airway in patients considered to be at risk for aspiration of gastric contents.

The goal of rapid sequence induction is to secure the patient airway smoothly and quickly minimising the chances of regurgitation and aspiration of gastric contents. Its use is indicated in the presence of full stomach in emergency situations and other situations where there is an increased risk of aspiration. Traditionally, suxamethonium has been the neuromuscular blocking drug of choice in rapid sequence induction and intubation technique. Yet its use is associated with a number of undesirable side effects like fasciculations, myalgia, hyperkalaemia, bradyarrhythmias, raised intraocular pressure, intracranial pressure, intragastric pressure, anaphylaxis, malignant hyperthermia and masseter 
spasm. ${ }^{4,5}$ Hence, it is not suitable in situations when patients have neuromuscular disorders, burns, head injury, intracranial bleeding, open eye injury and cerebrovascular accidents. The potential problems associated with suxamethonium have prompted the search for alternative methods, the use of non-depolarising muscle relaxants.

Rocuronium is a relatively newer non-depolarising muscle relaxant. It is expected to have an onset time, possibly as ratio as that of suxamethonium without its adverse side effects. But unlike suxamethonium, rocuronium has little or no cardiovascular side effects and does not cause histamine release. Thus, it is ideal for rapid sequence induction of anaesthesia and may be preferable to suxamethonium in compromised patients in whom cardiovascular effects are to be avoided. Also Rocuronium has intermediate duration of action, similar to that of vecuronium and atracurium and does not depend extensively on renal elimination, hepaticbiliary mechanisms primarily accounting for elimination.6,7

Rocuronium in a dose of $>0.9 \mathrm{mg} / \mathrm{kg}$ has been reported to offer intubating conditions at 60 secs that are similar to those observed with suxamethonium. The present study was designed to compare the endotracheal intubating conditions and haemodynamic responses of Rocuronium vs Suxamethonium

\section{Suxamethonium}

It is a depolarising neuromuscular blocker with rapid onset of effect and ultra-short duration of action. Suxamethonium is composed of 2 molecules of acetylcholine linked back to back through the acetyl methyl groups. Dosage: The ED95 of suxamethonium is $0.51-0.63 \mathrm{mg} / \mathrm{kg}$. Administration of 1 $\mathrm{mg} / \mathrm{kg}$ results in complete suppression of response of neuromuscular stimulation in approximately 60 seconds. The short duration of action is due to its rapid hydrolysis by the Butyrylcholinesterase to succinylmonocholine and choline.

\section{Rocuronium}

This is a monoquaternary amino steroidal non-depolarising neuromuscular blocking agent with shorter onset of action under intermediate duration of action. Rocuronium lacks the acetyl ester that is found in the steroidal nucleus of pancuronium and vecuronium in the A ring. The introduction of cyclic substitutes other than piperidine at the 2 and 16 positions resulted in fast-onset compound. The methyl group attached to the quaternary nitrogen of vecuronium and pancuronium is replaced by an allyl group in rocuronium, as the result of rocuronium at about 6 and 10 times was less potent than vecuronium.

Rocuronium act by combining with nicotinic acetyl choline (Ach) receptors without causing any activation of ion receptor channels. It undergoes minimal or no metabolism and is eliminated primarily by the liver and small fraction $(=10 \%)$ eliminated in urine. The initial dosage is determined by the purpose of administration.

Dose of intubation $0.6-1.0 \mathrm{mg} / \mathrm{kg}$, supplemental dose after intubation $0.1 \mathrm{mg} / \mathrm{kg}$. increasing the dose of Rocuronium from 0.6 (2× ED 95) to 1.2 (4× ED 95) $\mathrm{mg} / \mathrm{kg}$ shortened the onset time of complete neuromuscular blockade from $89 \pm 33$ seconds (mean \pm SD) to $55 \pm 14$ seconds, but significantly prolonged the clinical duration (recovery of $\mathrm{T} 1$ to $25 \%$ of baseline) from $37 \pm 15$ to $73 \pm 32$ minutes respectively.

\section{Sugammadex}

Is (Org 25969) a novel agent for reversal of neuromuscular blockade by the agent Rocuronium in general anaesthesia. It is the first selective relaxant binding agent. Sugammadex is a modified (placing eight carboxyl into ether group at the $6^{\text {th }}$ carbon positions) ${ }^{\gamma}$-cyclodextrin with a lipophilic core and a hydrophilic periphery.

\section{Factors Affecting the Speed of Onset of Neuromuscular Block}

Speed of onset of neuromuscular block is one of the requirements to rapidly secure the airway, and it is affected by several factors including the rate of delivery of the drug to the neuromuscular junction, receptor affinity, plasma clearance and the mechanism of neuromuscular blockade. The speed of onset is inversely proportional to the potency of non-depolarising neuromuscular blockers. A high ED 95 (low potency) is predictive of rapid onset and vice versa.

The differences in assessment of the quality of intubating conditions make comparison among studies difficult and sometimes impossible. So, the "Copenhagen Consensus in 1994" established a set of internationally acceptable guidelines for good clinical research practice in studies of neuromuscular blocking agents including intubation conditions.

\begin{tabular}{|c|c|c|c|}
\hline \multirow{2}{*}{ Variable } & \multicolumn{2}{|c|}{ Clinically Acceptable } & $\begin{array}{c}\text { Clinically } \\
\text { Unacceptable }\end{array}$ \\
\cline { 2 - 4 } & Excellent & Good & Poor \\
\cline { 4 - 4 } Laryngoscopy & Easy & Fair & Difficult \\
\hline $\begin{array}{c}\text { Vocal cords position } \\
\text { movement }\end{array}$ & $\begin{array}{c}\text { Abducted } \\
\text { None }\end{array}$ & $\begin{array}{c}\text { Intermediate } \\
\text { Moving }\end{array}$ & $\begin{array}{c}\text { Closed } \\
\text { Closed }\end{array}$ \\
\hline $\begin{array}{c}\text { Reaction to ETT } \\
\text { insertion and/or cuff } \\
\text { inflation: }\end{array}$ & None & $\begin{array}{c}\text { Slight } \\
\text { slight }\end{array}$ & $\begin{array}{c}\text { Vigorous } \\
\text { Sustained }\end{array}$ \\
$\begin{array}{c}\text { Movements of Limbs } \\
\text { Coughing }\end{array}$ & None & & \\
\hline
\end{tabular}

\section{A) Intubating Conditions:}

- Excellent: All qualities are excellent.

- Good: All qualities are either good or excellent.

- Poor: The presence of a single quality listed under "poor."

B) Laryngoscopy:

- Easy: Jaw relaxed, no resistance to blade in the course of laryngoscopy.

- Fair: Jaw not fully relaxed, slight resistance to blade.

- Difficult: Poor jaw relaxation, active resistance by the patient to laryngoscopy.

\section{Objectives}

The purpose of present study was to compare the onset time, intubating conditions of rocuronium and succinylcholine and to evaluate haemodynamic responses to these agents.8,9

\section{MATERIALS AND METHODS}

The clinical study was carried out after obtaining approval from the ethical committee, laryngoscopy and intubation and haemodynamic changes were compared in 50 patients of ASA Grade 1 and Mallampati Grade 1 between 18 - 60 years of age group, either sex undergoing elective surgical procedures under general anaesthesia requiring endotracheal intubation. Patients with morbid obesity, anticipated difficult airway 
(Mallampati grade 3 and 4), pregnancy, neuromuscular disorders, known allergy to study drugs were excluded from the study.

\section{Study Design and Setting}

All patients were randomly divided into two groups of 25 patients each using computer generated random number table and allocation concealment was done with closed sealed envelope technique. The patients were divided into two groups in randomised double-blind fashion. The intubating person was not aware of type of muscle relaxant used and waiting period from administration of muscle relaxant to intubation attempt. Group $\mathrm{S}(\mathrm{N}=25)$ patients received suxamethonium $1.5 \mathrm{mg} / \mathrm{kg}$ and Group $\mathrm{R}(\mathrm{N}=25)$ patients received Rocuronium $0.9 \mathrm{mg} / \mathrm{kg}$. Informed written consent was obtained. ${ }^{10,11}$

On arrival all the patients were pre-medicated with Inj. Glycopyrrolate $0.2 \mathrm{mg}$ IV 5 mins before surgery. Induction was achieved with Inj. Propofol $2 \mathrm{mg} / \mathrm{kg}$ IV followed by muscle relaxant, Inj. suxamethonium $1.5 \mathrm{mg} / \mathrm{kg}$ IV in Group S and Inj. Rocuronium $0.9 \mathrm{mg} / \mathrm{kg}$ IV in Group R. Sixty seconds after the relaxant administration, intubation was done and intubation condition were assessed as per the intubation scoring system of consensus conference on good clinical research practice in pharmacodynamic studies of neuromuscular blocking agents, Copenhagen consensus.

The haemodynamic variables (systolic blood pressure, diastolic blood pressure, mean arterial pressure, heart rate, oxygen saturation) were monitored continuously and recorded at time interval as below for analysis-

- $\mathrm{T} 1=$ Baseline.

- $\mathrm{T} 2=$ After induction and just before intubation.

- $\mathrm{T} 3=$ One minute after intubation.

- $\mathrm{T} 4=$ Two minutes after intubation.

- $\mathrm{T} 5=$ Three minutes after intubation.

- $\mathrm{T} 6=$ Four minutes after intubation.

- $\quad \mathrm{T} 7=$ Five minutes after intubation.

Duration of laryngoscopy and response of the patient during endotracheal intubation was observed at the time of intubation. Any changes in haemodynamic variables by $30 \%$ from the baseline value was considered as significant and managed accordingly. Anaesthesia was maintained, and no noxious stimulus was allowed during the study period of 5 minutes after intubation. ${ }^{12,13}$

At the end of surgery, the neuromuscular block was reversed by using Inj. atropine $0.02 \mathrm{mg} / \mathrm{kg}$ and Inj. neostigmine $0.04 \mathrm{mg} / \mathrm{kg}$ titrated according to response. Oropharyngeal suction was done, and patient was extubated when fully awake and when T1 had returned to $90 \%$ of the control.

\section{Statistical Analysis}

Statistical analysis was done using the software Statistical Package of Social Science version 20. Quantitative data viz. Haemodynamic parameters, age, weight, duration of laryngoscopy of the study groups were expressed in terms of mean \pm SD and conduct an unpaired ' $t$ ' test and one-way repeated measure (ANOVA) in SPSS. This includes both between subjects' factors and within subject factors.
Qualitative data viz. sex, weight and intubating conditions were compared across the group using chi-square test. Differences were considered statistically significant if $\mathrm{p}<0.01$ for all the above statistical analysis.

\section{RESULTS}

\begin{tabular}{|c|c|c|c|c|}
\hline $\begin{array}{l}\text { Sl. } \\
\text { No. }\end{array}$ & $\begin{array}{c}\text { Suxamethonium } \\
(n=25)\end{array}$ & $\begin{array}{c}\text { Rocuronium } \\
(n=25)\end{array}$ & $\begin{array}{c}\text { Total } \\
(n=50)\end{array}$ & \begin{tabular}{|c} 
Statistical \\
Significance
\end{tabular} \\
\hline 1 & Age Group (yrs.) & & & \\
\hline (a) & Less than 30 & $\begin{array}{c}6 \\
(16.0)\end{array}$ & $\begin{array}{c}4 \\
(24.0)\end{array}$ & \multirow{3}{*}{$\begin{array}{c}\chi 2=0.50 @ \\
(p=0.479) \\
d f=1\end{array}$} \\
\hline \multirow[t]{2}{*}{ (b) } & More than 30 yrs. & $\begin{array}{c}19 \\
(84.0)\end{array}$ & $\begin{array}{c}21 \\
(94.0)\end{array}$ & \\
\hline & Total & $\begin{array}{c}25 \\
(100.0)\end{array}$ & $\begin{array}{c}25 \\
(100.0)\end{array}$ & \\
\hline 2 & $\begin{array}{l}\text { Mean Age and } \\
\text { SD (yrs.) }\end{array}$ & $37.6 \pm 11.7$ & $41.3 \pm 11.3$ & $\begin{array}{c}\mathrm{t}=1.14{ }^{@} ; \\
\mathrm{p}=0.26\end{array}$ \\
\hline 3 & Mean Wt. SD & $44.8 \pm 7.2$ & $45.6 \pm 7.4$ & $\begin{array}{c}\mathrm{t}=0.36^{@} \\
\mathrm{p}=0.71\end{array}$ \\
\hline 4 & Sex & & & \\
\hline (a) & Male (1\%) & $\begin{array}{c}12 \\
(48.0)\end{array}$ & $\begin{array}{c}13 \\
(52.0)\end{array}$ & \multirow{3}{*}{$\begin{array}{c}\chi 2=0.08 @ \\
(p=0.777) \\
d f=1\end{array}$} \\
\hline (b) & Female $(1 \%)$ & $\begin{array}{c}13 \\
(52.0) \\
\end{array}$ & $\begin{array}{c}12 \\
(48.0) \\
\end{array}$ & \\
\hline & Total & $\begin{array}{c}25 \\
(100.0)\end{array}$ & $\begin{array}{c}25 \\
(100.0)\end{array}$ & \\
\hline
\end{tabular}

@ Not significant.

\begin{tabular}{|c|c|c|}
\hline Sl. No. & Group & $\begin{array}{c}\text { Duration of Laryngoscopy } \\
\text { (Sec) (Mean } \pm \text { SD) }\end{array}$ \\
\hline 1 & Suxamethonium & $18.68 \pm 6.97$ \\
\hline 2 & Rocuronium & $19.72 \pm 7.94$ \\
\hline & Total & $\mathbf{1 9 . 2 0} \pm 7.33$ \\
\hline \multicolumn{2}{|c|}{ Statistical significance } & $\mathrm{t}=0.492 @ ; \mathrm{p}=0.625$ \\
\hline \multicolumn{3}{|c|}{ Table 2. Duration of Laryngoscopy } \\
\hline
\end{tabular}

@ Not significant.

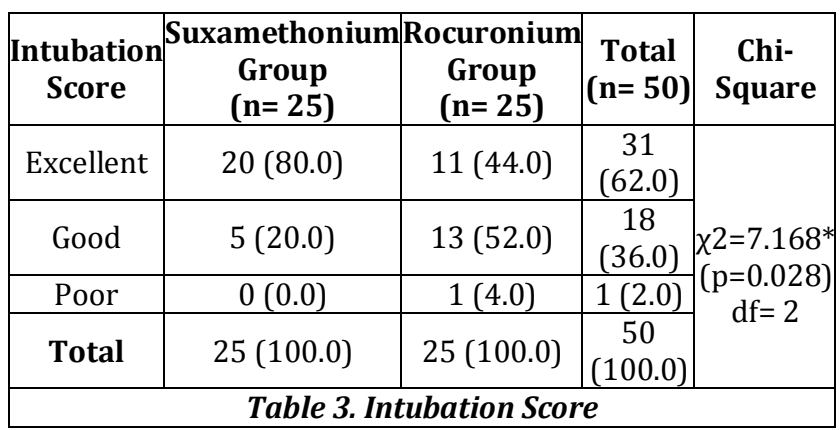

*Significant at 0.05 level $(\mathrm{p}<0.05)$.

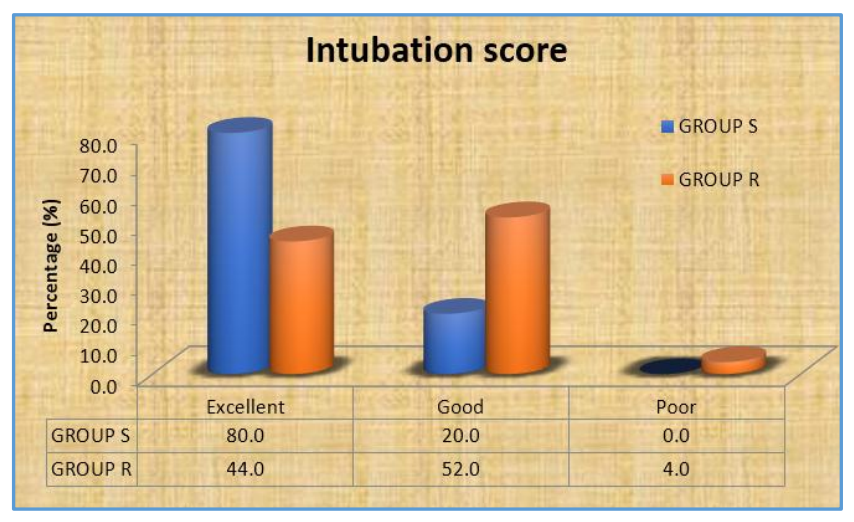

Figure 1. Comparison of the Overall Intubation Conditions 
The intubation conditions were graded as excellent in $20(80 \%)$ and $11(44 \%)$ patients of Group S and Group R respectively. The difference was statistically significant between Group S and Group R ( $p<0.05)$. In Group S (suxamethonium) $(n=25) 20$ patients had excellent intubating conditions, 5 patients had good intubating conditions and none of the patients had poor intubating conditions. In Group R (rocuronium) $(n=25) 11$ patients had excellent intubating conditions, 13 patients had good intubating conditions and one patient had poor intubating condition.

\begin{tabular}{|c|c|c|c|c|}
\hline \multicolumn{5}{|c|}{ Descriptive Statistics } \\
\hline \multirow{2}{*}{ Time } & Groups & Mean & $\begin{array}{c}\text { Std. } \\
\text { Deviation }\end{array}$ & N \\
\hline \multirow{4}{*}{ T1 } & Group R & 83.00 & 10.583 & 25 \\
\cline { 2 - 5 } & Group S & 79.40 & 11.053 & 25 \\
\cline { 2 - 5 } & Total & $\mathbf{8 1 . 2 0}$ & $\mathbf{1 0 . 8 6 3}$ & $\mathbf{5 0}$ \\
\hline \multirow{3}{*}{ T2 } & Group R & 85.04 & 9.973 & 25 \\
\cline { 2 - 5 } & Group S & 85.08 & 10.704 & 25 \\
\cline { 2 - 5 } & Total & $\mathbf{8 5 . 0 6}$ & $\mathbf{1 0 . 2 3 9}$ & $\mathbf{5 0}$ \\
\hline \multirow{4}{*}{ T3 } & Group R & 95.36 & 12.659 & 25 \\
\cline { 2 - 5 } & Group S & 92.12 & 13.430 & 25 \\
\cline { 2 - 5 } & Total & $\mathbf{9 3 . 7 4}$ & $\mathbf{1 3 . 0 1 9}$ & $\mathbf{5 0}$ \\
\hline \multirow{3}{*}{ T4 } & Group R & 93.32 & 12.110 & 25 \\
\cline { 2 - 5 } & Group S & 86.08 & 15.223 & 25 \\
\cline { 2 - 5 } & Total & $\mathbf{8 9 . 7 0}$ & $\mathbf{1 4 . 0 9 6}$ & $\mathbf{5 0}$ \\
\hline \multirow{3}{*}{ T5 } & Group R & 90.80 & 11.772 & 25 \\
\cline { 2 - 5 } & Group S & 83.84 & 15.448 & 25 \\
\cline { 2 - 5 } & Total & $\mathbf{8 7 . 3 2}$ & $\mathbf{1 4 . 0 4 0}$ & $\mathbf{5 0}$ \\
\hline \multirow{3}{*}{ T6 } & Group R & 85.20 & 10.332 & 25 \\
\cline { 2 - 5 } & Group S & 79.12 & 12.804 & 25 \\
\cline { 2 - 5 } & Total & $\mathbf{8 2 . 1 6}$ & $\mathbf{1 1 . 9 1 7}$ & $\mathbf{5 0}$ \\
\hline \multirow{3}{*}{ T7 } & Group R & 83.60 & 10.575 & 25 \\
\cline { 2 - 5 } & Group S & 79.00 & 11.083 & 25 \\
\cline { 2 - 5 } & Total & $\mathbf{8 1 . 3 0}$ & $\mathbf{1 0 . 9 7 0}$ & $\mathbf{5 0}$ \\
\hline & Table 4. Changes in the Mean Heart Rate \\
\hline & & & & \\
\cline { 2 - 5 } & & & \\
\hline
\end{tabular}

Note: Group S: Suxamethonium; Group R: Rocuronium;

1. Mauchly's test of sphericity value 116.278; significant at $\mathrm{p}<0.001$ level (within time intervals).

2. Within-subjects' effects time ${ }^{*}$ groups were not significant.

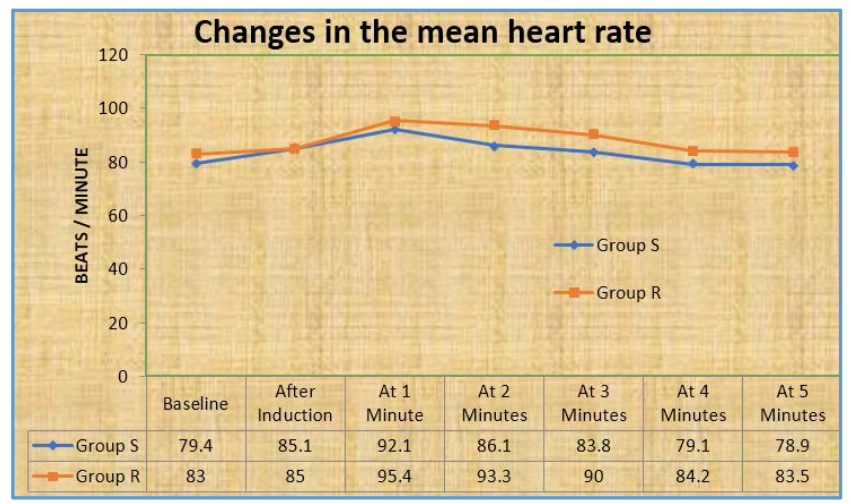

Figure 2. Comparison of Heart Rate Variations
Heart rate was comparable $(p>0.05)$ between both groups, (Group $S$ and $R$ ) at baseline after induction and during the study period of 5 mins after intubation. However, in both the groups (Group S and R), patient's heart rate increased significantly at 0.001 level from the baseline up to 3 mins after intubation and came to below the baseline value during fourth and fifth minute after intubation.

\begin{tabular}{|c|c|c|c|c|}
\hline \multicolumn{5}{|c|}{ Descriptive Statistics } \\
\hline \multirow{2}{*}{ Time } & Groups & Mean & $\begin{array}{c}\text { Std. } \\
\text { Deviation }\end{array}$ & N \\
\hline \multirow{3}{*}{ T1 } & Group R & 114.00 & 11.619 & 25 \\
\cline { 2 - 5 } & Group S & 115.52 & 11.095 & 25 \\
\cline { 2 - 5 } & Total & $\mathbf{1 1 4 . 7 6}$ & $\mathbf{1 1 . 2 7 0}$ & $\mathbf{5 0}$ \\
\hline \multirow{3}{*}{ T2 } & Group R & 106.24 & 9.597 & 25 \\
\cline { 2 - 5 } & Group S & 107.84 & 10.180 & 25 \\
\cline { 2 - 5 } & Total & $\mathbf{1 0 7 . 0 4}$ & $\mathbf{9 . 8 2 5}$ & $\mathbf{5 0}$ \\
\hline \multirow{4}{*}{ T3 } & Group R & 122.32 & 12.938 & 25 \\
\cline { 2 - 5 } & Group S & 125.36 & 12.526 & 25 \\
\cline { 2 - 5 } & Total & $\mathbf{1 2 3 . 8 4}$ & $\mathbf{1 2 . 6 9 6}$ & $\mathbf{5 0}$ \\
\hline \multirow{3}{*}{ T4 } & Group R & 120.48 & 14.917 & 25 \\
\cline { 2 - 5 } & Group S & 122.80 & 10.677 & 25 \\
\cline { 2 - 5 } & Total & $\mathbf{1 2 1 . 6 4}$ & $\mathbf{1 2 . 8 9 2}$ & $\mathbf{5 0}$ \\
\hline \multirow{3}{*}{ T5 } & Group R & 117.08 & 15.349 & 25 \\
\cline { 2 - 5 } & Group S & 116.92 & 9.823 & 25 \\
\cline { 2 - 5 } & Total & $\mathbf{1 1 7 . 0 0}$ & $\mathbf{1 2 . 7 5 4}$ & $\mathbf{5 0}$ \\
\hline \multirow{2}{*}{ T6 } & Group R & 112.20 & 10.817 & 25 \\
\cline { 2 - 5 } & Group S & 113.52 & 9.010 & 25 \\
\cline { 2 - 5 } & Total & $\mathbf{1 1 2 . 8 6}$ & $\mathbf{9 . 8 7 5}$ & $\mathbf{5 0}$ \\
\hline \multirow{3}{*}{ T7 } & Group R & 111.48 & 10.763 & 25 \\
\cline { 2 - 5 } & Group S & 111.88 & 8.964 & 25 \\
\cline { 2 - 5 } & Total & $\mathbf{1 1 1 . 6 8}$ & $\mathbf{9 . 8 0 5}$ & $\mathbf{5 0}$ \\
\hline Table 5. Changes in the Mean Systolic Blood Pressure \\
\hline
\end{tabular}

Note: Group S: Suxamethonium; Group R: Rocuronium;

1. Mauchly's test of sphericity value 190.979; significant at $\mathrm{p}<0.001$ level (within time intervals).

2. Within-subjects' effects time ${ }^{*}$ groups were not significant.

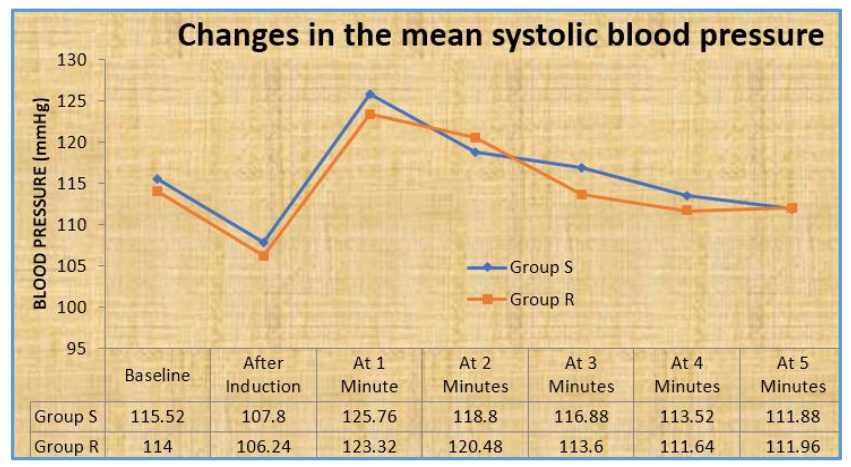

Figure 3. Comparison of Mean Systolic Blood Pressure

Comparison of mean systolic blood pressure was not significant $(p>0.05)$ between both groups at baseline, after induction and during the study period of 5 mins after intubation. However, in both the groups (Group S and R), patient's systolic blood pressure increased significantly at 0.001 level from the baseline up to 3 mins after intubation and came to below the baseline value during $4^{\text {th }}$ and $5^{\text {th }}$ minute after intubation. When compared clinically, SBP values were within $30 \%$ from the baseline value in both groups. ${ }^{14}$ 


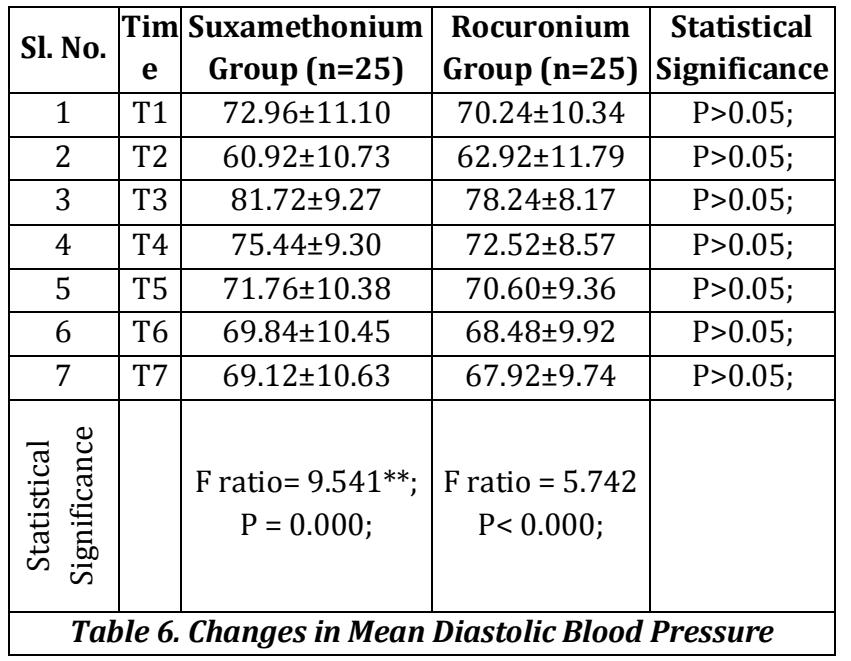

@- Not significant; ${ }^{* *}$ significant at 0.01 level $(\mathrm{p}<0.01)$.

\begin{tabular}{|c|c|c|c|c|}
\hline \multirow{5}{*}{ Time } & Groups & Mean & $\begin{array}{c}\text { Std. } \\
\text { Deviation }\end{array}$ & N \\
\hline \multirow{3}{*}{ T1 } & Group R & 70.24 & 10.349 & 25 \\
\cline { 2 - 5 } & Group S & 72.96 & 11.107 & 25 \\
\cline { 2 - 5 } & Total & $\mathbf{7 1 . 6 0}$ & $\mathbf{1 0 . 7 1 3}$ & $\mathbf{5 0}$ \\
\hline \multirow{3}{*}{ T2 } & Group R & 62.92 & 11.797 & 25 \\
\cline { 2 - 5 } & Group S & 60.92 & 10.731 & 25 \\
\cline { 2 - 5 } & Total & $\mathbf{6 1 . 9 2}$ & $\mathbf{1 1 . 2 0 6}$ & $\mathbf{5 0}$ \\
\hline \multirow{4}{*}{ T3 } & Group R & 78.24 & 7.666 & 25 \\
\cline { 2 - 5 } & Group S & 81.72 & 9.271 & 25 \\
\cline { 2 - 5 } & Total & $\mathbf{7 9 . 9 8}$ & $\mathbf{8 . 6 0 1}$ & $\mathbf{5 0}$ \\
\hline \multirow{3}{*}{ T4 } & Group R & 72.52 & 8.579 & 25 \\
\cline { 2 - 5 } & Group S & 75.44 & 9.301 & 25 \\
\cline { 2 - 5 } & Total & $\mathbf{7 3 . 9 8}$ & $\mathbf{8 . 9 7 7}$ & $\mathbf{5 0}$ \\
\hline \multirow{4}{*}{ T5 } & Group R & 70.60 & 9.363 & 25 \\
\cline { 2 - 5 } & Group S & 71.76 & 10.381 & 25 \\
\cline { 2 - 5 } & Total & $\mathbf{7 1 . 1 8}$ & $\mathbf{9 . 8 0 1}$ & $\mathbf{5 0}$ \\
\hline \multirow{2}{*}{ T6 } & Group R & 68.48 & 9.921 & 25 \\
\cline { 2 - 5 } & Group S & 69.84 & 10.455 & 25 \\
\cline { 2 - 5 } & Total & $\mathbf{6 9 . 1 6}$ & $\mathbf{1 0 . 1 1 0}$ & $\mathbf{5 0}$ \\
\hline \multirow{3}{*}{ T7 } & Group R & 67.92 & 9.738 & 25 \\
\cline { 2 - 5 } & Group S & 69.12 & 10.631 & 25 \\
\cline { 2 - 5 } & Total & $\mathbf{6 8 . 5 2}$ & $\mathbf{1 0 . 1 0 8}$ & $\mathbf{5 0}$ \\
\hline
\end{tabular}

Note: Group S: Suxamethonium; Group R: Rocuronium;

1. Mauchly's test of sphericity value 145.551; significant at $\mathrm{p}<0.001$ level (within time intervals).

2. Within-subjects' effects time ${ }^{*}$ groups were not significant.
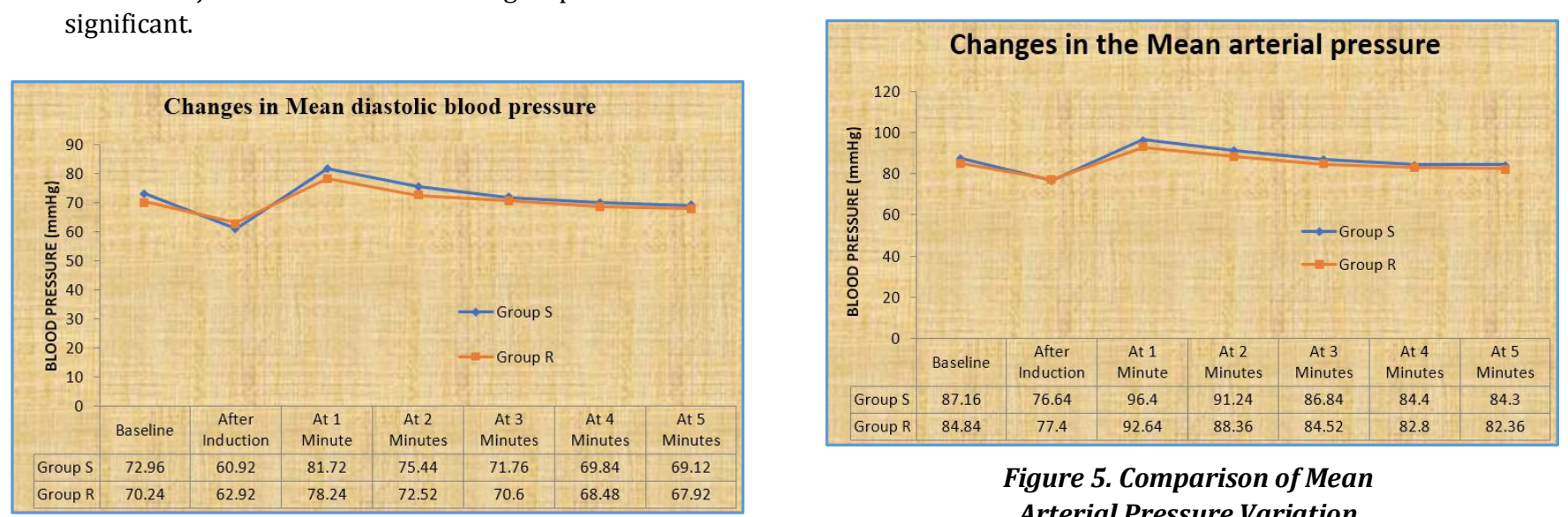

Figure 5. Comparison of Mean Arterial Pressure Variation

Note: Group S: Suxamethonium; Group R: Rocuronium;

1. Mauchly's test of sphericity value 151.021; significant at $\mathrm{p}<0.001$ level (within time intervals).

2. Within-subjects' effects time * groups were not significant.

Figure 4. Comparison of Mean Diastolic Blood Pressures 
Mean arterial pressure was comparable $(p>0.05)$ between both groups, (Group S and R) at baseline, after induction and during the study period of 5 mins after intubation. However, in both the groups, patient's mean arterial pressure increased significantly $\mathrm{p}<0.001$ from the baseline up to 3 mins after intubation and came to below the baseline value during $4^{\text {th }}$ and $5^{\text {th }}$ minute after intubation. When compared clinically, MAP values were within $30 \%$ from the baseline value in both groups.

\section{DISCUSSION}

An ideal muscle relaxant should therefore have nondepolarising mechanism of action, rapid onset, short duration, rapid recovery, non-cumulative, no histamine release, no cardiovascular side effects, high potency and prompt reversibility by cholinesterase inhibitors and pharmacologically inactive metabolites. 16

\section{CONCLUSION}

The following conclusions can be drawn from the above study. Both groups were comparable haemodynamically and had comparable clinically acceptable intubating conditions, although suxamethonium group had better intubation scores indicating the quality of intubation with suxamethonium is better than rocuronium. This proves that suxamethonium is still the "gold standard" for tracheal intubation. However, in conditions where suxamethonium is contraindicated, Rocuronium in a dose of $0.9 \mathrm{mg} / \mathrm{kg}$ can be used to intubate the trachea at 60 seconds.

It establishes the usefulness of Rocuronium in $0.9 \mathrm{mg} / \mathrm{kg}$ as a safer and better alternative to succinylcholine in conditions where the latter is contraindicated or hazardous.

\section{REFERENCES}

[1] Naguib M, Cynthia LA, Pharmacology of muscle relaxants and their antagonists. Chapter - 13. In: Miller RD, edr. Miller's Anaesthesia. $6^{\text {th }}$ edn. Philadelphia: Churchill Livingstone 2005: p. 481-547.

[2] Cooper R, Mirakhur RK, Clarke RSJ, et al. Comparison of intubating conditions after administration of Org 9426 (Rocuronium) and Suxamethonium. British Journal of Anaesthesia 1992;69(3):269-73.

[3] Huizinga AC, Vandenbrom RH, Wierda JM, et al. Intubating conditions and onset of neuromuscular block of Rocuronium (Org 9426): a comparison with Suxamethonium. Acta Anaesthesia Scand 1992;36(5):463-8.

[4] Puhringer FK, Khuenl-Brady KS, Koller J, et al. Evaluation of endotracheal intubating conditions of Rocuronium (ORG 9426) and Succinylcholine in outpatient surgery. Anaesth Analg 1992;75(1):37-40.
[5] Kreig N, Mazur L, Booj LH, et al. Intubation conditions and reversibility of a new non-depolarizing neuromuscular blocking agent, Org-NC45. Acta Anaesthesia Scand 1980;24(5):423-5.

[6] McCourt KC, Salmela L, Mirakhur RK, et al. Comparison of Rocuronium and Suxamethonium for use during rapid sequence induction of anaesthesia. Anaesthesia 1998;53(9):867-71.

[7] Ajeet S, Kumar BP, Lal TK. Comparison of onset time, duration of action and intubating conditions achieved with Suxamethonium and Rocuronium. Indian J Anaesthesia 2004;48(2):129-33.

[8] Agoston S, Salt P, Newton D, et al. The neuromuscular blocking action of ORG NC45, a new pancuronium derivative in anaesthetized patients. British Journal of Anaesthesia 1980;(52 Suppl 1):53S-9S.

[9] Mirakhur RK, Ferres CJ, Clarke RSJ, et al. Clinical evaluation of ORG NC45. British Journal of Anaesthesia 1983;55(2):119-24.

[10] Mirakhur RK, Lavery GG, Clarke RSJ, et al. Atracurium in clinical anaesthesia: effect of dosage on onset, duration and conditions for tracheal intubation. Anaesthesia 1985;40(8):801-5.

[11] Plaud E, Meistelman C, Donati F. Organon 9426 neuromuscular blockade at the adductor muscles of the larynx and adductor pollicis in man. Anaesthesiology 1991;75:A784.

[12] Koh KF, Chen FG. Rapid tracheal intubation with atracurium: the timing principle. Can J Anaesth 1994;41(8):688-93.

[13] Sieber TJ, Zbinden AM, Curatolo M, et al. Tracheal intubation with rocuronium using the "timing principle". Anaesth Analg 1998;86(5):1137-40.

[14] Larsen PB, Hansen EG, Jacobsen LS, et al. Intubation conditions after rocuronium or succinylcholine for rapid sequence induction with alfentanil and propofol in the emergency patients. Eur J Anaesthesiol 2005;22(10):748-53.

[15] Laurin EG, Sakles JC, Panacek EA, et al. A comparison of succinylcholine and rocuronium for rapid- sequence intubation of emergency department patients. Acad Emerg Med 2000;7(12):1362-9.

[16] Fuch-Buder T, Tassonyi E. Intubating conditions and time course of rocuronium-induced neuromuscular block in children. British Journal of Anaesthesia 1996;77(3):335-8. 